\title{
Prosecution of Legal Entities: History, Theory, Practice and Proposals
}

\author{
${\text { Bokhodir Isroilov }{ }^{1},{ }^{*} \text { Gaybulla Alimov }{ }^{1} \text {, Bobokul Toshev }}^{1}$ \\ ${ }^{I}$ The Lawyers Training Centre under the Ministry of Justice of the Republic of Uzbekistan, Tashkent State University \\ of Economics, Uzbekistan \\ *Email: b.isroilov@tsue.uz
}

\begin{abstract}
The article considers the history of the legal entities' responsibility, their responsibility in the legislation of developed countries, the general classification of legal entities of Anglo-Saxon and Romano-Germanic legal families, types of legal entities, features of the responsibility of legal entities in individual countries, the conditions for their release. Criminal law covers legal entities' liability, statutory obligations, collective responsibility issues, types of punishments applied to legal entities, and their application's specifics. Problems of legal entities liability in the criminal law of the Republic of Uzbekistan, some aspects of the inclusion of criminal liability of legal entities in the draft of the new Criminal Code of the Republic of Uzbekistan, the positions of supporters and opponents of legal scholars of Uzbekistan on the criminal liability of legal entities, the validity of these provisions from the point of view of the theory of criminal law and legislation Of the Republic of Uzbekistan, the alleged areas of application of the criminal liability of legal entities and the types of sanctions applied to legal entities.
\end{abstract}

Keywords: Crimes of legal entities, Anglo-Saxon and Romano-Germanic legal families, Statutory obligations, Criminal law, Collective criminal liability, Types of punishments imposed on legal entities, Scopes of punishment, Privileges.

\section{INTRODUCTION}

The ongoing economic integration processes in the countries of the world and the positive aspects of economic development, also lead to the development of negative consequences that are dangerous for society and the state. As a result of integration, positive changes in the world economy and an improvement in the population's quality of life have a negative impact on money laundering and financing of terrorism and corruption.

According to the United Nations (UN), the annual turnover of funds related to corruption worldwide is 1 trillion dollars. As a result, the world economy will receive 2.6 trillion dollars and that this loss is estimated at 5 per cent of global GDP [1]. Analysis of UN data shows that this category of offences is international, and its consequences represent a real social threat, with negative implications for both developed and developing countries. Thus, to ensure the fight against corruption by international organisations:

- International Code of Ethics for Public Officials (New York, December 12, 1996);

- Criminal Law Convention on Corruption (Strasbourg, January 27, 1999);

- Civil Liability Convention on Corruption (Strasbourg, November 4, 1999) ) and the Additional Protocol to this Convention (Strasbourg, May 15, 2003)

- Adopted documents such as the UN Convention against Corruption (October 31, 2003).

These documents are currently serving to improve national legislation.

Corruption is the most dangerous social evil that seriously undermines the development of the state and society; people's trust in justice and public administration since the solution of socio-economic problems in society 
depends on governance. In many countries of the world, various reforms are currently being carried out to ensure economic growth, which improves living standards. Regardless of how positive the purpose of these reforms is, some create conditions for corruption to grow and flourish. This is because conservative views in society, customs and minor flaws in the legislation, hindering the implementation of reforms, seriously affect the effective implementation of these laws. World practice shows that only the adoption of laws cannot eliminate corruption in society.

\section{MATERIALS AND METHODS}

Based on the study purpose, the opinions of local and foreign scientists, government agencies and particular websites are used to determine the liability of legal entities for corruption offences, methods such as systematic analysis, comparative analysis, logic and grouping are used to develop appropriate recommendations.

\section{DISCUSSION}

\subsection{The need to fight corruption}

The socio-economic development of any country depends on the effectiveness of the administrative apparatus. In countries with economies in transition, a vast bureaucratic apparatus impedes its development and interferes with the state's efforts to implement market reforms and social objectives. To prevent such a situation, the state needs to reform the administrative system and adapt it to modern requirements. This requires an in-depth study of the national management system and world experience of each country and the implementation of administrative reforms based on a serious critical analysis of the activities of all levels of government.

International banking experts acknowledge that 40 per cent of entrepreneurs worldwide, 15 per cent in developed countries, 30 per cent in Asian countries, and 60 per cent in CIS countries are forced to pay bribes [2].

Therefore, international organisations such as the UN, OSCE, EU, FATF are developing rules for combating corruption. The process of integrating the system of international cooperation in the fight against corruption is being strengthened. A method for evaluating the world's countries' work in the fight against corruption has been created.

\subsection{The situation of the fight against corruption in Uzbekistan}

Corruption is the illegal use of a position or position for personal or group purposes for profit or another gain. It is known that the loss of public confidence in government agencies is the most dangerous socially negative sign that leads to the commission of corruption crimes in society. The state's role and authority are weakening because of deteriorating public confidence in the state apparatus. As a result, various political crises and protests arose, and the shadow economy's share increased. Thus, it is recognised that several reforms are being carried out in Uzbekistan to ensure economic stability and reform anti-corruption mechanisms [3].

However, despite the measures taken and the improvement of the legal framework and preventive and advocacy work, the number of corruption-related crimes in Uzbekistan remains high (figure 1).

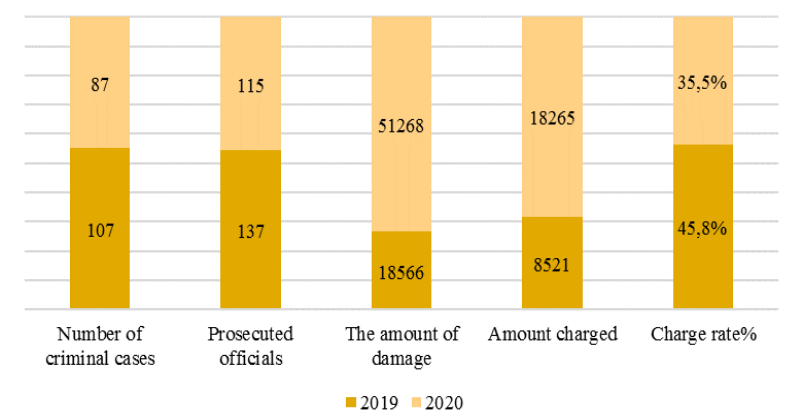

Figure 1 Analysis of corruption crimes committed in Uzbekistan in 2019-2020.

According to the table, only $35.5 \%$ of the damage caused by crimes was recovered. In our opinion, the main reason for the small amount of compensation for damage to the country's economy is that the current criminal code does not provide for liability for legal entities, as most of the materially damaged legal entities are organisations with billions in their accounts.

\subsection{Criminal liability of legal entities and international practice}

A negative consequence of the world economy's integration process is the growth of corruption in the corporate sector. These types of crimes are committed mainly in the interests of legal entities. However, in most states' legislation, especially in the former Soviet Union countries, legal entities are not considered the subject of a crime for this type of crime. As a result, in exchange for prosecuting a person, the crime's root remains unclear, and measures to eliminate its consequences and the formation of mechanisms remain outside legal practice.

Therefore, recognising the responsibility of a legal entity in the commission of corruption crimes and legal entities' existence is rightly emphasised by the world community. Criminal liability is currently imposed on legal entities in more than 70 countries worldwide (table $1)$.

The introduction of the institution of criminal prosecution of legal entities has a long history. In feudal 
Europe, the range of subjects subject to criminal liability was not limited, and animals and inanimate objects could also be prosecuted by law. In particular, in France's 1618th centuries, there was a criminal prosecution procedure for corporations and communities [4].

In the 15-17th centuries, the principle of personal responsibility, proclaimed by the Great French Revolution, was introduced into the practice of countries belonging to the Romano-Germanic legal system's family. In the European countries' practice, the USA and Canada, which belong to the family of common law, by the 18th century, the negative attitude towards corporate criminalisation began to change in the opposite direction.

In her research, E.V. Epifanova notes that legal entities' criminal liability in the United States was constitutionally recognised by the U.S. Supreme Court in 1909 [5]. In the United States, corporate criminal liability was constitutionally recognised in 1909 by the United States Supreme Court. Since the UK common law system forms the US criminal law system, the prosecution of legal entities for corrupt acts in modern US criminal law is sufficiently interpreted in federal and state criminal law. In Ohio, Pennsylvania, Georgia, and many other US states, the type of punishment for corporate crimes is defined as a fine and both at the federal and state levels.

The liability of legal entities in American law has an extraordinarily complex structure, different states have different rules, and they differ sharply from similar institutions in other states. In our opinion, some of the penalties imposed by the United States for the crimes of legal entities are beneficial for the Republic of Uzbekistan. Therefore, it is recommended to include such types of fines as fines and legal entities' limitation for a certain period [6].
From the mid-19th century, judges in Britain began to find corporations in the country guilty of violating their statutory obligations. After that, the idea of corporate persecution in the UK will start to be recognised. Researchers studying the British Companies Act 1989 content conclude that corporate criminal liability is fully reflected in the law [7].

As a result of the study of Australia's legal system, E. Trikoz supported researcher E. Yu. Antonov's opinion on this matter, who states that corporations do not commit real crimes, so it is wrong to accuse them [8].

Until recently, the institution of legal entities' liability for corrupt acts was recognised primarily as an institution-specific to Anglo-American criminal law. However, globalisation is leading to an increase in corruption crimes committed in the interests of corporations. To prevent this type of crime, the institution of legal entities' liability has been introduced in more than 70 countries.

Countries such as Austria, Albania, Spain, Latvia, Mexico and Peru have taken an "interim" approach to prosecuting legal entities for corruption offences. Although a legal entity is not the subject of a formal crime in these countries, they are subject to various criminal sanctions. The sanctions imposed on legal entities are criminal.

The Austrian Criminal Code does not explicitly provide for legal entities' criminal liability; it only applies to a larger number of individuals. However, suppose a legal entity illegally enriches itself or owns property because of a crime committed by an individual. In that case, it is stipulated that "the legal entity is subject to a fine in the amount of the illegally enriched one" [9]. A

Table 1. States where criminal liability is established for legal entities

\begin{tabular}{|l|c|c|}
\hline \multicolumn{1}{|c|}{ № } & Country name & $\begin{array}{c}\text { The year in which the criminal } \\
\text { sentence was imposed }\end{array}$ \\
\hline 1. & Australia, UK, Ireland & 1997 \\
\hline 2. & Belgium, Hungary & 2001 \\
\hline 3. & Denmark, Israel, Iceland & 1998 \\
\hline 4. & Canada, China & 1997 \\
\hline 5. & The Netherlands & 1976 \\
\hline 6. & Norway & 1991 \\
\hline 7. & Poland & 2002 \\
\hline 8. & Romania & 2004 \\
\hline 9. & Slovenia & 1999 \\
\hline 10. & USA, Finland & 1995 \\
\hline 11. & France & 1992 \\
\hline 12. & Switzerland & 2003 \\
\hline 13. & Luxembourg & 2010 \\
\hline 14. & Czech Republic & 2012 \\
\hline
\end{tabular}


similar legal framework is used in Albania, Spain, Latvia, Mexico and Peru.

Belgian law provides that if a company employee is harassed, the company will be sanctioned if they served the company's interests.

Although legal entities' criminal liability is a product of civil law relations, and although this situation is mostly affected by civil law relations, it does not exclude legal entities' criminal liability. Likewise, harassment of corporate executives and other officials does not preclude criminal sanctions against the corporation. We consider it reasonable to apply sanctions to them in the form of fines, forced dismissal, revocation of work permits.

The issue of corporate criminal responsibility has received a lot of international support in the last century. In particular, in 1929, at the international congress on topical matters of criminal law in Bucharest, appropriate recommendations were adopted approving its application. In 1946, the international tribunal at Nuremberg ruled in court that states and their organisations should target a transnational crime. In 1978, the Council of Europe on Crime recommended that EU member states' legislatures include legal entities as environmental crime subjects. One such international instrument is Recommendation 18 of the Council of Ministers of the European Union (88). It provides that legal entities engaged in economic activities in all countries of the Council of Europe should be held accountable for offences or crimes committed in their economic activities [9]

Today the world economy operates through legal entities both nationally and internationally. Legal entities are often not private entrepreneurs, but various commercial companies compete with each other in public procurement, fighting with regulators to obtain the necessary permits to operate. Transport, construction, telecommunications, mining, chemical production and various other industries are controlled by large corporations and companies and act globally. Thus, in a real situation, a high level of corruption serves the interests of legal entities.

Also, the complexity of the management system in such large corporations and companies, the fact that decisions are made collectively makes it difficult to bring legal entities to justice and solve crimes. Thus, the participants and perpetrators of the crime avoid responsibility by admitting that criminal decisions were made in a collegial manner. The increase in the number of corruption crimes for corporate purposes in the international arena in recent years requires adopting measures to prevent them and establish legal entities' liability for the crimes committed.

\section{CONCLUSION}

Researchers have recognised that a culture of honesty and business acumen is an essential informal institution of market relations, and the presence of such corporate elements can reduce morale and material costs, reduce risks and serve for effective long-term market activity (Errou, 1972), (Fukuyama, 1995, p. Denison and Mishra, 1995, Guizo et al., 2015, Garret et al., 2014, Guiso et al. (2015) [10]

The research work shows that the determination of legal entities' liability for corruption offences is private and social. However, the research results on this topic show that legal scholars' views on the issue of liability of legal entities differ.

Nikofirova A.S. who studied the content of the British Companies Law of 1989, believes that the corporation is guilty of a crime committed due to managerial actions or negligence of the director, manager, secretary or another official of the corporation [7]. When studying the problem of collective responsibility in Australian criminal law, a researcher J. Hein notes that legal entities' responsibility for crimes in the field of taxation, trade and the environment is determined [11]. Dutch criminal law may prescribe all penalties that can be enforced by legal entities for the commission of any crime. The primary type of punishment is acceptable, which is applied in six amounts depending on the severity of the act committed by the legal entity [12]

At present, Uzbekistan's legislation defines the liability of legal entities only in civil and economic legislation. However, there is no criminal or administrative liability for legal entities' actions in our country's corporate interests. In recent years, this topic has been the subject of heated discussions in our country's various scientific and political circles. A group of scientists and politicians believes that the current legislation provides legal entities' civil and economic liability, so there is no need to amend the legislation [13]. The second group of scientists [14] noted that reforms in Uzbekistan, the integration of the country's economy into the world economy and the ratification by the Oliy Majlis of several international legal documents relating to the liability of legal entities require the establishment of criminal or administrative liability of legal entities states.

Legal persons can be held liable for any crime under Dutch criminal law. However, according to the Supreme Court of the Netherlands' decision, public authorities cannot be held criminally responsible as a legal entity.

In our opinion, it is inappropriate to establish liability of legal entities for crimes related to the life, health and safety of individuals. At present, based on the Concept developed based on the Resolution of the President of the Republic of Uzbekistan "On measures to improve the system of criminal and criminal procedure legislation 
radically", measures are being taken to include a separate chapter on "Criminal sanctions" for legal entities.

In this regard, in recent years, this topic has been the subject of heated debates in our country's various scientific and political circles.

The research results show that in Uzbekistan, as well as scientists from around the world, there is no single solution to this problem.

The need to determine the institution of liability of legal entities' evolutionary direction can be realised only through the legal formation of practices such as liability of legal entities, national traditions, knowledge of local conditions, and work experience on the territory of Uzbekistan

As part of the civil law reforms, new forms of legal entities are emerging, which requires further improvement of the institution of legal entity liability. Organisations benefit their members, provide jobs and services and shape and strengthen the country's budget.

The Republic of Uzbekistan's Government provides legal entities with a wide range of legal assistance, opportunities, and preferences in the effective organisation of their economic activities. In this case, enterprises have great potential for effective organisation of their actions, control and inspection bodies cannot act illegally, and interference is limited. In this context, in our opinion, the sense of responsibility and accountability of legal entities should increase. Only as a result of the system's adaptation for increasing the responsibility and accountability of legal entities to the requirements of international standards will mechanisms for the adequate protection of the rights, freedoms and interests of citizens and the country be formed.

The problem itself and the imperfection of national legislation, the discrepancy between current needs and economic life, the incomplete formation of a scientifically grounded system, and the need to develop legislation reflect the features of legal entities' corrupt practices. Thus, the new edition of the draft codes of criminal and administrative responsibility of the Republic of Uzbekistan includes separate chapters on the responsibility of legal entities, the prevention of corporate corruption and ensuring the country's adherence to the UN Convention against Corruption and the positive change in the country's index system serves.

\section{REFERENCES}

[1] B.I. Isroilov, U. Abduganiev, B.B. Ibragimov, Financial control of public procurement to prevent corruption in the development of the digital economy, 2020. Retrieved from: 10.2991/aebmr.k.2005.02.089
[2] Yu.L. Kolesnikov, B.I. Isroilov, K.V. Shvetsov, N.G. Karimov, I.S. Khotamov, G.Sh. Karabaeva, A.A. Islamov. Workbook, St. Petersburg Polytechnic University, SPB, 2018.

[3] Anti-Corruption Network for Eastern Europe and Central Asia, The third round of monitoring, Uzbekistan, interim report. Retrieved from: http://www.oecd.org/corruption/acn

[4] E.Yu. Antonova, Criminal liability of legal entities: monograph, Ed. prof. A.I. Korobeeva, Vladivostok, 2010, p. 164.

[5] E.V. Epifanova, A legal entity as a subject of a crime, Modern law, M., Ed. New Index 2 (2003) 4345 (teriladim).

[6] B.I. Isroilov, Strengthening the liability of legal entities for corruption offences, Bishkek, "Izvestia" international theoretical and scientific-practical journal, Iss. 2, 2018.

[7] A.S. Nikiforov, Legal entity as a subject of crime and criminal liability, M., 2002, p. 51.

[8] E.N. Trikoz, Evolution of the system of sources and primary criminal law institutions in Australia in the 19th and 20th centuries: Diss. Cand. jurid. Sciences: 12.00.01, M., 2002, p. 103

[9] E.Yu. Antonova, Legal entity as a subject of crime: foreign countries' experience and prospects of application in Russia, M., 2003, p. 3.

[10] W.Y. Wong, Are state ownership and auditors' locality determinants of asset write-downs? Evidence from China, China Journal of Accounting Research Vol. 11 Iss. 4 (2018) 385-405.

[11] G. Heine, Collective criminal responsibility, Law and Politics 7 (2001) 50.

[12] Criminal Code of Holland. Scientific adviser professor B.V. Volzhensky, St. Petersburg, 2001, p. 55.

[13] B. Axrarov, M. Baratov, Some aspects of legal entities' responsibility in the Republic of Uzbekistan, Justice 5 (2020) 35-41.

[14] G.A. Alimov, A system of international standards governing the liability of legal entities for corruption offences. -T., KOMRON PRESS, MChJ, 2019, p. 35,146 . 